\title{
PENGARUH EDUKASI FARMASIS TERHADAP KEPATUHAN DAN KONTROL GLIKEMIK PASIEN DM TIPE 2 PENGGUNA INSULIN DI POLIKLINIK PENYAKIT DALAM RSUD BAYU ASIH KABUPATEN PURWAKARTA TAHUN 2013
}

\author{
Suharti ${ }^{*}$, Swasono R. Tamat ${ }^{2}$, Sesilia A. Keban ${ }^{3}$ \\ 1,2,3 Universitas Pancasila \\ *Korespondensi: Jl. Veteran, No. 272 Ciseureuh Purwakarta. Email : hartipoenya@gmail.com
}

\begin{abstract}
ABSTRAK
Latar Belakang: Diabetes Melitus (DM) merupakan sekelompok kelainan heterogen yang ditandai dengan kenaikan kadar glukosa dalam darah atau hipeglikemia yang terjadi karena kelainan sekresi insulin, kerja insulin atau kedua-keduanya. Terapi obat yang aman dan efektif akan terjadi apabila pasien mempunyai pengetahuan yang cukup tentang obat-obat dan penggunaannya.
\end{abstract}

Tujuan Penelitian: untuk mengetahui peran farmasis dalam edukasi pasien DM dan kaitannya dengan faktor-faktor yang mempengaruhi kontrol glikemik pasien DM tipe 2 di Poliklinik Penyakit Dalam RSUD Bayu Asih Kabupaten Purwakarta.

Metode Penelitian: ini merupakan penelitian ekperimental dengan pengambilan data yang dilakukan secara prospektif. Pasien dikelompokkan menjadi 3 kelompok dengan masing-masing kelompok terdiri dari 20 orang yang mendapatkan edukasi oleh farmasis dengan frekuensi yang berbeda-beda, yaitu kelompok yang mendapatkan edukasi 2 kali, kelompok yang mendapatkan edukasi 3 kali, dan kelompok yang mendapatkan edukasi 4 kali. Tingkat pengetahuan pasien terhadap pengobatan diukur dengan menggunakan instrumen Medication Knowledge Assesment (MKA), sedangkan tingkat kepatuhan pasien diukur menggunakan instrumen Modified Morisky Scale (MMS). Data dianalisis secara deskriptif dan secara kuantitatif menggunakan uji T independen dan uji T berpasangan.

Hasil penelitian: hasilnya menunjukan pasien kelompok 2 kali edukasi, kelompok 3 kali edukasi dan kelompok 4 kali edukasi, semuanya mengalami kenaikan pada tingkat pengetahuan dan kepatuhan. Selain itu pasien pada ketiga kelompok tersebut juga mengalami penurunan kadar Gula Darah Puasa (GDP) dan kadar Gula Darah dua jam PP (GD2JPP), namun ternyata perbedaan frekuensi pemberian edukasi tidak berpengaruh terhadap tingkat pengetahuan, kepatuhan dan juga kadar gula darah pasien. Penelitian menyimpulkan bahwa edukasi farmasis dapat meningkatkan pengetahuan dan kepatuhan pengobatan. Tidak ada korelasi antara kepatuhan pasien dan kontrol glikemik, namun ada korelasi positif antara frekuensi edukasi dan kadar glukose darah 2 jam post prandial.

Simpulan: Dapat disimpulkan juga bahwa frekuensi edukasi mempengaruhi kepatuhan dan kontrol glikemik.

Kata-kata kunci: edukasi farmasis, pengetahuan, kepatuhan, DM tipe-2, Medication Knowledge Assesment, Modified Morisky Scale

\begin{abstract}
Background: Diabetes mellitus (DM) is a heterogeneous group of disorders characterized by an increase in blood glucose levels or hiperglikemia that occurs due to abnormal insulin secretion, insulin action or both. Drug therapy is safe and effective would happen if patients were given enough information about medicine and its usage.

objectives This study aims to determine the role of pharmacists in educating patients about diabetes melitus and its relation with factors that influencing glycemic control in type 2 diabetes patients, in Internal Disease Clinic at Bayu Asih Purwakarta Hospital.
\end{abstract}


Methods: The study is an experimental study conducted using Nonrandomized Concurrent Control Trial prospectively. Patients were devided into three groups with 20 patients in each group, who were given education by pharmacist with different frequency, first group given education twice, second group given education 3 times, and third group given education 4 times. Patient's knowledge on medication were measured by the Medication Knowledge Assessment (MKA), whereas adherence to medication were measured using Modified Morisky Scale (MMS). Data collected were analyzed descriptively and also quantitatively by independent $t$ test and paired t test.

Result. The results showed that the patients in the group 2 times education, group 3 times education and group 4 times education, all of them experienced an increase in the level of knowledge and compliance. In addition, patients in the three groups also experienced a decrease in their fasting blood sugar (GDP) and two-hour blood sugar levels (GD2JPP), however, the difference in the frequency of education did not affect the level of knowledge, compliance and also blood sugar levels of patients. The study concluded that pharmacist education can improve knowledge and medication adherence. There was no correlation between patient adherence and glycemic control, but there was a positive correlation between frequency of education and blood glucose levels 2 hours post prandial. There are no correlation between adherence and glycemic control, but is a positive correlation between frequency of education and 2 hour post prandial blood glucose level.

Conclusion. It can be cocluded also that frequency of education can influence on adherence and glycemic control.

Keywords: pharmacist education, knowledge, adherence, type 2 DM, Medication Knowledge Assessment, Modified Morisky Scale

\section{PENDAHULUAN}

Diabetes melitus merupakan suatu kelompok penyakit metabolik dengan karakteristik hiperglikemia yang terjadi karena kelainan sekresi insulin, kerja insulin atau kedua-duanya. Terdapat dua tipe Diabetes Melitus yaitu DM tipe 1 (IDDM / Insulin Dependent Diabetes Melitus) merupakan akibat dari destruksi sel beta pulau Langerhans yang berakibat defisiensi hormon insulin absolut dan DM tipe 2 (NIDDM / Non-Insulin Dependent Diabetes Melitus) merupakan akibat dari adanya resistensi insulin sehingga hormon insulin dalam tubuh tidak dapat berfungsi dengan semestinya (1).

Laporan Centers for Disease and Prevention (CDP) Tahun 2007 menyebutkan bahwa prevalensi DM di seluruh dunia mencapai $4 \%$ penduduk dunia dan diprediksi akan mencapai 5,4\% pada tahun 2025. Jumlah penderita DM di Cina dan India mencapai 50 juta orang. Sedangkan di Amerika Serikat merupakan jenis penyakit peringkat ke-enam penyebab kematian. Dari sekian banyak jumlah penderita DM di seluruh dunia tersebut, sebanyak 10\% merupakan penderita DM tipe 1 dan 90\% adalah penderita DM tipe 2 yang dapat menyerang semua kelompok umur dan biasanya disertai penyakit-penyakit lainnya seperti jantung koroner, infeksi pankreas serta jenis penyakit degeneratif lainnya (2).

Angka kesakitan dan kematian akibat DM di Indonesia cenderung berfluktuasi setiap tahunnya sejalan dengan perubahan gaya hidup masyarakat. Pada tahun 2010 diperkirakan jumlah penderita DM di Indonesia mencapai lebih dari 5 juta dan di dunia sebesar 239,9 juta penderita (3). Di Indonesia berdasarkan data terbaru dari kementerian kesehaan, penderita penyakit diabetes mellitus sekitar 1,5\% sampai $2,3 \%$ atau sekitar 1,25 juta penduduk, dengan perbandingan laki-laki perempuan adalah 1,5:1 (3).

Di Jawa Barat sendiri penderita diabetes mellitus sekitar 5,6\% dari jumlah penduduknya, sedangkan di sekitar Jawa Barat seperti Kabupaten Purwakarta prevalensi penderita diabetes mellitus berkisar $1,1 \%$ dari jumlah penduduknya. Data dari Dinas Kesehatan Propinsi Jawa Barat Tahun 2011 menunjukkan bahwa 
jumlah pasien diabetes melitus yang berobat jalan ke Rumah Sakit di Provinsi Jawa Barat sekitar 13.759 orang, sedangkan yang menjalani rawat inap sebanyak 4.410 orang (3).

Laporan pola penyakit RSUD Bayu Asih Kabupaten Purwakarta pada tahun 2011, menyebutkan penyakit DM menempati urutan nomor 1 dari 10 kunjungan penyakit degeneratif. Jumlah kunjungan penderita DM selama kurun waktu satu tahun terakhir sebanyak 5100 kunjungan, yang terdiri dari 394 kasus DM $(7,73 \%)$ rawat inap dan 4706 kasus DM $(92,3 \%)$ rawat jalan dengan 461 kasus baru. Diabetes mellitus telah menjadi salah satu penyebab kematian terbesar di wilayah kerja RSUD Bayu Asih, Kabupaten Purwakarta Jawa Barat (4).

Data Sistem Informasi dan Manajemen Rumah Sakit (SIMRS) RSUD Bayu Asih, menunjukkan bahwa jumlah pasien DM yang berkunjung ke RSUD Bayu Asih, Kabupaten Purwakarta Jawa Barat selama kurun waktu 3 (tiga) tahun terakhir mengalami peningkatan yang cukup signifikan. Pada tahun 2009 jumlah pasien DM yang berkunjung sebanyak 637 pasien dengan jumlah pasien yang dirawat inap sebanyak 295 pasien dan yang di rawat jalan sebanyak 342 pasien. Tahun 2010 mengalami peningkatan menjadi 708 pasien dengan jumlah pasien yang menjalani rawat inap sebanyak 323 pasien dan yang berobat jalan sebanyak 385 pasien. Tahun 2011 jumlah pasien DM sebanyak 786 pasien yang terdiri dari pasien rawat inap sebanyak 392 pasien dan rawat jalan sebanyak 394 pasien (4).

Menurut laporan Department of Health and Human Service (DHHS) tahun 1990, 48 \% dari seluruh penduduk Amerika serikat, dan $55 \%$ geriatri, dalam beberapa hal, gagal mengikuti regimen pengobatan (5). Meskipun ketidakpatuhan tidak selalu menimbulkan konsekuensi, penelitian menunjukkan bahwa $25 \%$ pasien ini akan menggunakan obat dengan cara yang dapat membahayakan kesehatan pasien. Ketidakpatuhan dapat memperpanjang masa sakit atau meningkatkan keparahan penyakit. Tinjauan literatur rmemperlihatkan bahwa $11 \%$ pasien masuk rumah sakit akibat ketidakpatuhan terhadap terapi obat ${ }^{(5)}$.

Berbagai penelitian menunjukkan bahwa kepatuhan pasien pada pengobatan penyakit yang bersifat kronis pada umumnya rendah. Penelitian yang melibatkan pasien berobat jalan menunjukkan bahwa lebih dari $70 \%$ pasien tidak minum obat sesuai dengan dosis yang seharusnya (6). Menurut laporan WHO pada tahun 2003, kepatuhan rata-rata pasien pada terapi jangka panjang terhadap penyakit kronis di negara maju hanya sebesar 50\%, sedangkan di negara berkembang, jumlah tersebut bahkan lebih rendah (6). Ketidakpahaman pasien terhadap terapi yang sedang dijalaninya akan meningkatkan ketidakpatuhan pasien dalam mengkonsumsi obatnya (7). Faktor tersebut akibat dari kurangnya informasi dan komunikasi antara tenaga kesehatan dengan pasien dan biasanya karena kurangnya informasi mengenai hal-hal di atas, maka pasien melakukan self-regulation terhadap terapi obat yang diterimanya (7)

\section{METODE}

Penelitian ini merupakan penelitian ekperimental dilakukan dengan menggunakan rancangan uji kontrol bersamaan nonrandom (Nonrandomized Concurrent Control Trial) secara prospektif. Data dianalsis secara deskriptif dan secara kuantitatif menggunakan uji t independen, uji $t$ berpasangan dan uji regresi linear. penelitian dilakukan selama 2 (dua) bulan dengan langkah pertama adalah melakukan seleksi pasien. Kemudian pasien dikelompokkan menjadi 3 kelompok dengan masing-masing kelompok sebanyak 20 sample penelitian yang nanti akan mendapatkan perlakuan yang berbeda yaitu frekunsi pemberian edukasi farmasis.

Kelompok pertama diberikan edukasi farmasis dengan memberikan konseling dan alat bantu seperti brosur dan sebagainya sebanyak 2 (dua) kali, kelompok kedua sebanyak 3 (tiga) kali dan kelompok ketiga sebanyak 4 (empat) kali. Pertemuan kedua dan ketiga adalah pada saat pasien kontrol di Poliklinik Penyakit Dalam dan mengambil obat-obatan di Instalasi Farmasi yang biasanya dilakukan 2 (dua) minggu 
sekali sesuai dengan kebijakan asuransi penjaminnya yaitu memberikan obat pasien yang masuk dalam kategori penyakit kronis untuk 2 minggu.

Masing-masing kelompok sebelum mendapat perlakuan dilakukan pengukuran tingkat pengetahuan terhadap penyakitnya, pengetahuan terhadap pengobatan, kontrol glikemik dan pengukuran kepatuhan untuk pertama kalinya. Selanjutnya masingmasing kelompok akan mendapatkan perlakuan yang sama yaitu edukasi farmasis dengan materi yang berbeda dengan edukasi farmasis saat pertemuan pertama, yang membedakan adalah frekuensi pemberian edukasi farmasis tersebut.

Setelah diberikan edukasi farmasis, selanjutnya dilakukan pengukuran untuk kedua kalinya menggunakan instrumen yang sama yaitu mengukur pengetahuan terhadap pengobatan, kontrol glikemik dan pengukuran tingkat kepatuhan.

\section{HASIL PENELITIAN DAN PEMBAHASAN}

\section{A. KARAKTERISTIK RESPONDEN}

\section{Karakteristik} Berdasarkan Jenis Kelamin

Dari jumlah responden sebanyak 60 orang yang terbagi menjadi 3 kelompok yaitu 20 responden untuk kelompok yang mendapatkan edukasi sebanyak 2 kali, 20 responden untuk kelompok yang mendapatkan edukasi sebanyak 3 kali dan 20 responden untuk kelompok yang mendapatkan edukasi sebanyak 4 kali ternyata sebagian besar berjenis kelamin wanita.

Karakteristik responden berdasarkan jenis kelamin selengkapnya dapat dilihat pada Grafik V.1 dibawah ini.

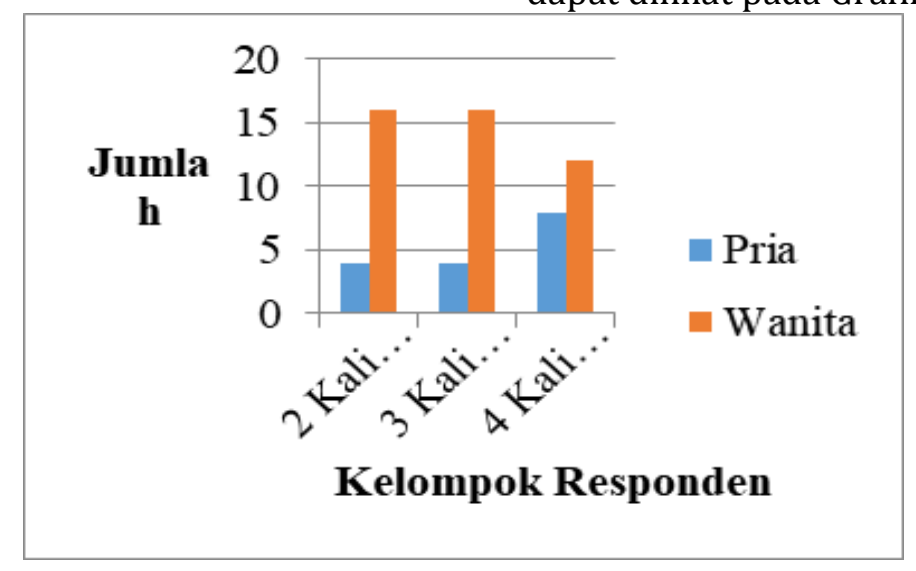

\section{Grafik1 Karakteristik Responden Berdasarkan Jenis Kelamin}

Berdasarkan Grafik 1, dapat dilihat bahwa dari total 60 responden:

Laki-laki $=16$ responden $(26,67 \%)$, Wanita $=44$ responden $(73,33 \%)$.

Untuk kelompok 2 kali edukasi:

Laki-laki 4 responden $(20 \%)$ dan Wanita $16=$ responden $(80 \%)$. kelompok 3 kali edukasi:

Laki-laki 4 responden $(20 \%)$ dan Wanita 16 responden (80\%)

kelompok 4 kali edukasi,

Laki-laki 8 responden (40 \%) dan 12 Wanita responden $(60 \%)$ 


\section{Karakteristik responden Berdasarkan Usia}

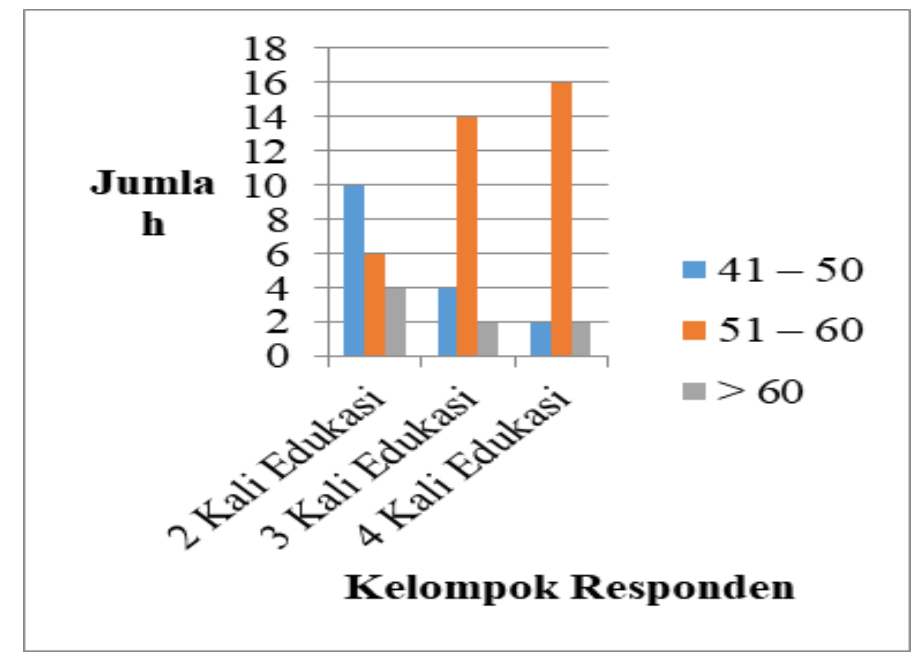

Dari Grafik 2 dapat diketahui bahwa:

Pada kelompok 2 kali edukasi: usia antara 41-50 tahun $=10$ responden (50\%), usia 51-60 tahun $=6$ responden $(30 \%)$ usia diatas 60 tahun $=4$ responden $(20 \%)$.

\section{Kelompok 3 kali edukasi:}

Usia antara 51-60 tahun $=14$ responden $(70$ $\%)$, usia 41-50 tahun $=4$ responden $(20$ $\%$ usia diatas 60 tahun $=2$ responden $(10 \%)$.

\section{Kelompok 4 kali edukasi:}

Usia antara 51-60 tahun $=16$ responden 80 $\%)$, kemudian responden yang usia 41-50 tahun $\quad=2$ responden $(10 \%)$ usia diatas 60 tahun $\quad=2$ responden $(10 \%)$. Hasil penelitian diatas sesuai dengan penelitian yang dilakukan oleh Nadyah Awad dkk pada Tahun 2012 (31) yang membagi kelompok usia pasien menjadi 6 (enam) kelompok yaitu usia 21-30 tahun, usia 31-40 tahun, usia 41-50 tahun, usia 5160 tahun, usia 61-70 tahun dan usia $>70$ tahun. Namun karena dari data penelitian yang didaat ternyata rentang usia responden adalah tidak ada yang dibawah 40 tahun, maka pengelompokan pasien berdasarkan usia adalah 41-50 tahun, 51-60 tahun dan $>60$ tahun.

\section{Karakteristik Berdasarkan Pekerjaan}

Karakteristik responden berdasarkan pekerjaan dibagi menjadi 4 kelompok jenis pekerjaan yaitu yang bekerja sebagai Pegawai Negeri Sipil (PNS) aktif, Pegawai Swasta, Pensiunan (PNS atau swasta) dan sebagai ibu rumah tangga.

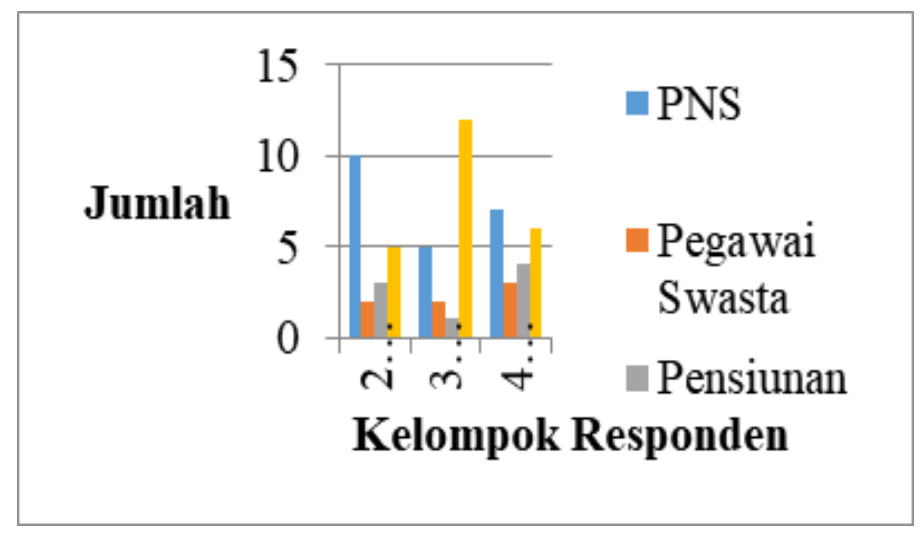

Grafik 3 Karakteristik Responden Berdasarkan Pekerjaan 
Berdasarkan Grafik 3 dapat diketahui bahwa:

\section{pada kelompok 2 kali edukasi:}

PNS aktif $=10$ responden (50\%), ibu rumah tangga $=5$ responden $(25 \%)$, Pegawai pensiunan $=3$ respondan $(15 \%)$ pegawai swasta $=2$ responden $(10 \%)$.

kelompok 3 kali edukasi:

Ibu rumah tangga $=12$ responden (60\%), PNS aktif $=5$ responden (25\%), Pegawai swasta $=2$ responden $(10 \%)$ dan terakhir adalah pensiunan $=1$ responden $(5 \%)$.

Kelompok 4 kali edukasi:

PNS aktif $=7$ responden (35\%), Ibu rumah tangga $=6$ responden $(30 \%)$, pegawai pensiun $=4$ responden $(20 \%)$ dan pegawai swasta $=3$ responden $(15 \%)$.

\section{Karakteristik Responden Berdasarkan Tingkat Pendidikan}

Karateristik responden berdasarkan tingkat pendidikan diperlukan sebagai dasar analisa untuk menilai tingkat pengetahuan dan kepatuhan. Secara logika, responden yang memiliki tingkat pendidikan lebih tinggi semestinya memiliki tingkat pengetahuan yang lebih baik dibandingkan dengan responden yang tingkat pendidikannya lebih rendah. Selengkapnya dapat dilihat dalam grafik dibawah ini

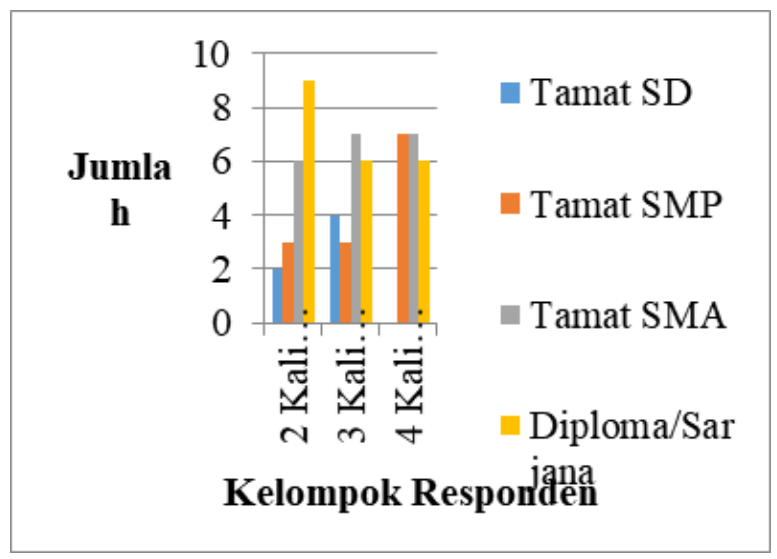

\section{Grafik 4 Karakteristik Responden Berdasarkan Tingkat Pendidikan}

Dari Grafik 4 dapat diketahui bahwa:

pada kelompok 2 kali edukasi :

prosentase tingkat pendidikan paling banyak adalah responden yang lulus Diploma atau Sarjana : 9 responden (45\%) yang paling banyak, tamat SMA $=6$ responden $(30 \%)$, tamat $\mathrm{SMP}=3$ responden $(15 \%)$ tamat $\mathrm{SD}=2$ responden $(10 \%)$.

\section{Untuk kelompok 3 kali edukasi ;}

Prosentase tingkat pendidikan paling banyak adalah responden yang tamat SMA = 7 Responden (35\%) yang paling banyak, lulus Diploma atau Sarjana: 6 responden (30\%), tamat SD $=4$ respondan $(20 \%)$ dan terakhir adalah tamatan SMP $=3$ responden $(15 \%)$.

\section{kelompok 4 kali edukasi:}

Prosentase tingkat pendidikan paling banyak adalah responden yang tamat SMA dan SMP dengan jumlah responden sama banyak yaitu masing-masing 7 responden (35\%), kemudian yang lulus Diploma atau Sarjana sebanyak 6 responden (30\%) dan tidak ada responden yang tamat SD

\section{Karakteristik Berdasarkan Lama Sakit \\ Lama sakit dibagi menjadi 3} kelompok yaitu: $<5$ tahun, kemudian yang lama sakitnya antara 5-10 tahun dan kelompok terakhir > 10 tahun. Selengkapnya dapat dilihat pada grafik dibawah ini: 


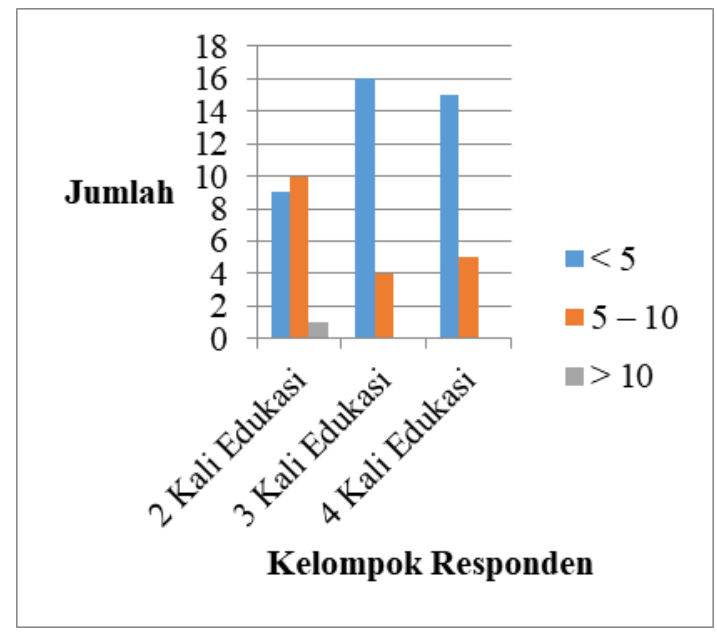

\section{Grafik 5 Karakteristik Responden Berdasarkan Lama Sakit}

Dari grafik 5 dapat diketahui bahwa:

pada kelompok 2 kali edukasi:

prosentase lama sakit paling banyak adalah responden yang menderita DM antara 5 10 tahun yaitu sebanyak 10 responden (50 $\%)$, yang lama sakit $<5$ tahun sebanyak 9 responden (45\%) yang lama sakit $>10$ tahun hanya sebanyak 1 responden (5\%).

\section{Kelompok 3 kali edukasi:}

prosentase lama sakit paling banyak adalah responden yang menderita DM: $<5$ tahun yaitu sebanyak 16 responden (80 \%), antara 5 - 10 tahun sebanyak 4 responden (20\%) dan yang lama sakit lebih $>10$ tahun tidak ada.

kelompok 4 kali edukasi:

Hampir sama dengan kelompok yang $3 \mathrm{kali}$ edukasi, prosentase lama sakit paling banyak adalah responden yang menderita DM kurang dari 5 tahun yaitu sebanyak 15 responden (75\%), kemudian siasanya adalah yang lama antara 5 - 10 tahun sebanyak 5 responden (25\%) dan yang lama sakit lebih dari 10 tahun tidak ada.

\section{Karakteristik Responden Berdasarkan Penyakit Penyerta pada pasien yang sudah menderita} DM lebih dari 5 tahun memiliki resiko terjadinya komplikasi. Sehingga jarang ditemui pasien DM yang sudah 5 tahun lebih yang tanpa adanya penyakit penyerta Karakteristik responden berdasarkan penyakit penyerta selengkapnya dapat dilihat pada grafik 6 dibawah ini.

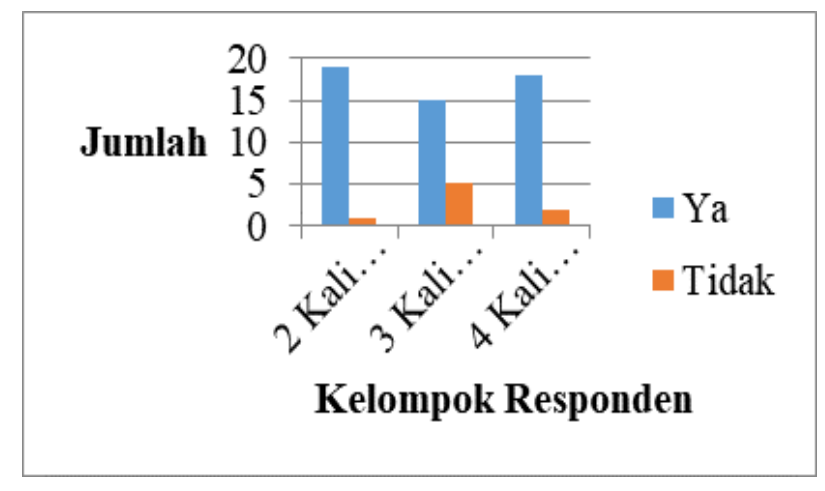

Grafik. 6 Karakteristik Responden Berdasarkan Penyakit Penyerta.

Berdasarkan grafik 6 dapat diketahui pada kelompok 2 kali edukasi :

bahwa hampir semua responden mengalami komplikasi atau penyakit penyerta yaitu sebanyak 19 responden (95 \%) dan hanya 1 responden saja (5 \%) yang tidak mengalami komplikasi atau penyakit penyerta. 
kelompok 3 kali edukasi :

15 responden (75 \%) yang mengalami komplikasi atau penyakit penyerta. 5 responden (25\%) yang tidak mengalami komplikasi atau penyakit penyerta.

kelompok 4 kali edukasi :

responden mengalami komplikasi atau penyakit penyerta :18 responden (90\%) yang tidak mengalami komplikasi atau penyakit penyerta $=2(10 \%)$
7. Karakteristik

Responden

Berdasarkan Kadar Gula Puasa (GDP)

Gula darah puasa ini memiliki makna yang cukup signifikan dalam penegakan diagnosis penyakit DM. Kadar normal Gula Darah Puasa pada orang dewasa adalah 70 - $110 \mathrm{mg} / \mathrm{dL}$. Akan tetapi menurut American Diabetes Association (ADA) dan Perkumpulan Endokrinologi Indonesia (PERKENI) bahwa kadar Gula Darah Puasa seseorang yang menderita DM adalah $126 \mathrm{mg} / \mathrm{dL}$ atau lebih (2).

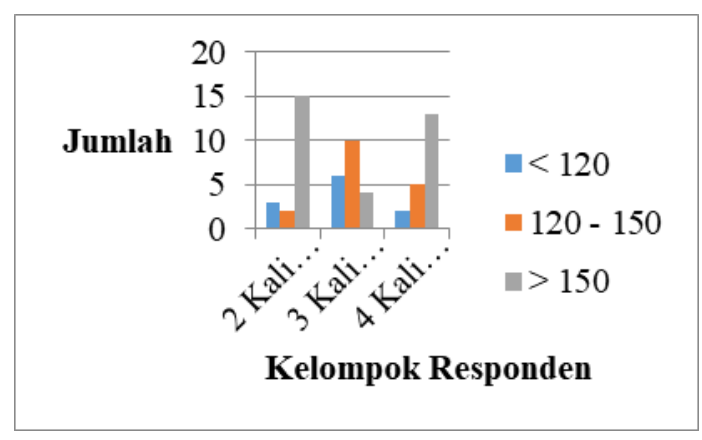

\section{Grafik 7 Karakteristik Responden Berdasarkan Gula Darah Puasa (GDP)}

Dari grafik 7 dapat diketahui bahwa:

\section{kelompok 2 kali edukasi:}

kadar gula darah puasa (GDP) > $150 \mathrm{mg} / \mathrm{dL}$ = 15 responden (75\%), kadar gula darah puasa (GDP) $<120 \mathrm{mg} / \mathrm{dL}=3$ responden (15\%) kadar gula darah puasa (GDP) antara $120-150 \mathrm{mg} / \mathrm{dL} .=2$ responden $(10 \%)$

\section{kelompok 3 kali edukasi:}

kadar gula darah puasa (GDP) antara 120 $150 \mathrm{mg} / \mathrm{dL}=10$ responden (50\%) kadar gula darah puasa (GDP) kurang dari 120 $\mathrm{mg} / \mathrm{dL}=6$ responden $(30 \%)$ kadar gula darah puasa (GDP) diatas $150 \mathrm{mg} / \mathrm{dL} .=4$ responden $(20 \%)$

\section{kelompok 4 kali edukasi:}

kadar gula darah puasa (GDP) antara 120 $150 \mathrm{mg} / \mathrm{dL}=13$ responden (65\%) kadar gula darah puasa (GDP) kurang dari 120 $\mathrm{mg} / \mathrm{dL}=5$ responden $(25 \%)$ kadar gula darah puasa (GDP) diatas $150 \mathrm{mg} / \mathrm{dL} .=2$ responden(10\%)

\section{Karakteristik Responden Berdasarkan Kadar Gula 2 Jam PP (GD 2JPP)}

Gula Darah 2 Jam post prandial (GD 2JPP) adalah kadar gula dalam darah yang diambil pada seseorang yang sebelumnya telah menjalani puasa selama minimal 8 jam kemudian makan (buka puasa) dan setelah 2 jam dilakukan pemeriksaan kadar gula darahnya, Selengkapnya lihat grafik dibawah ini: 


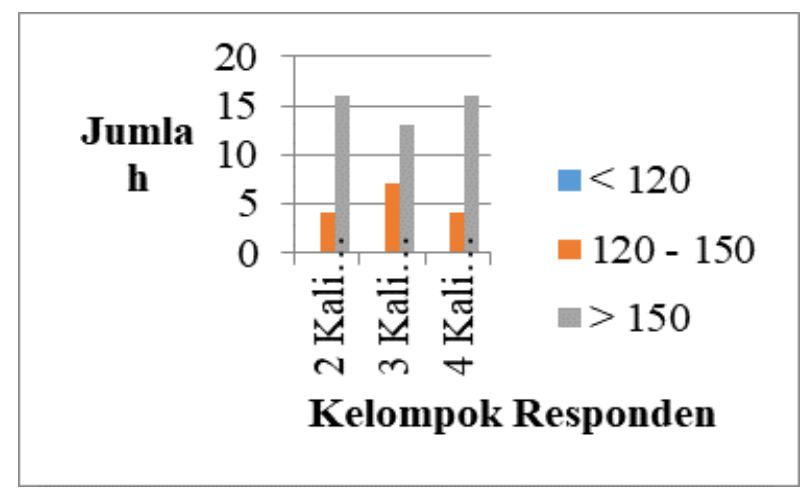

\section{Grafik 8 Karakteristik Responden Berdasarkan Gula Darah 2 Jam PP (GD 2JPP)}

Dari garfik 8 dapat diketahui bahwa:

\section{kelompok 2 kali edukasi:}

kadar gula darah 2 jam post prandial (GD $2 \mathrm{JPP})>150 \mathrm{mg} / \mathrm{dL},=16$ responden $(80 \%)$ (20\%) dengan kadar gula darah 2 jam post prandial (GD 2JPP) antara 120 - 150 $\mathrm{mg} / \mathrm{dL}=4$ responden $(20 \%)$ kadar gula darah 2 jam post prandial (GD 2JPP) kurang dari $120 \mathrm{mg} / \mathrm{dL}$. Tidak ada kelompok 3 kali edukasi:

kadar gula darah 2 jam post prandial (GD 2JPP) diatas $150 \mathrm{mg} / \mathrm{dL}$, = 13 responden (65\%) kadar gula darah 2 jam post prandial (GD 2JPP) antara $120-150 \mathrm{mg} / \mathrm{dL}=7$ (35\%) kadar gula darah 2 jam post prandial (GD 2JPP) kurang dari $120 \mathrm{mg} / \mathrm{dL}$ tidk ada

\section{kelompok 4 kali edukasi;}

kadar gula darah 2 jam post prandial (GD 2JPP) diatas $150 \mathrm{mg} / \mathrm{dL}=16$ responden (80 $\%)$, kadar gula darah 2 jam post prandial (GD 2JPP) antara $120-150 \mathrm{mg} / \mathrm{dL}=4$ responden (20\%) kadar gula darah 2 jam post prandial (GD 2JPP) kurang dari 120 $\mathrm{mg} / \mathrm{dL}$ tidak ada.

\section{B. TINGKAT PENGETAHUAN}

1. Pengetahuan Terhadap Penyakit DM Pengetahuan pasien mengenai penyakit DM, dinilai menggunakan kuesioner sederhana tentang penyakit DM yang meliputi pengertian, faktor penyebab, faktor resiko, komplikasi dan pengobatan DM dan pertanyaan tentang pengaturan diet untuk penderita DM. Terdapat 10 buah pertanyaan dengan model pilihan berganda 3 option tetap yaitu A (Ya), B (Tidak) dan C (Tidak Pasti). Pasien diukur pengetahuan awalnya sebelum mendapatkan edukasi. Selengkapnya ada pada tabel dibawah ini:

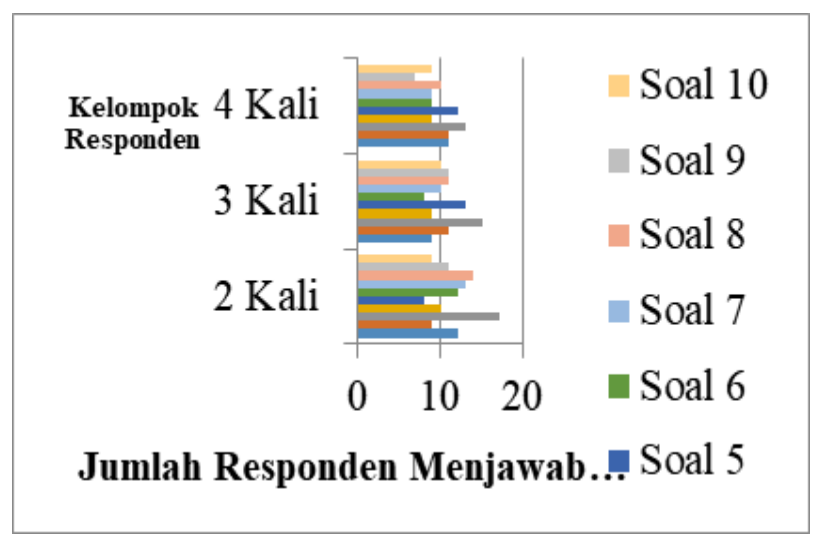

Grafik 9 Pengetahuan Terhadap Penyakit DM

Dari grafik 9, ketiga kelompok diatas, maka pasien sudah sangat memahami bahwa penyakit DM dapat diobati, sehingga edukasi perlu ditekankan pada pertanyaan no. 5,6 dan 9 . 
Rata-rata jumlah responden yang menjawab benar tertinggi pada kelompok yang mendapatkan 2 kali edukasi yaitu 11,5 (57,5\%), kemudian pada kelompok yang mendapatkan 3 kali yaitu 10,7 (53,5\%) dan paling rendah adalah pada kelompok yang mendapatkan 4 kali edukasi edukasi yaitu 10 (50\%). Penilaian tingkat pengetahuan terhadap ketiga kelompok edukasi hanya dilakukan sekali pada awal bertemu dengan pasien. Alat ukur ini tidak di validasi sehingga tidak bisa digunakan sebagai pembanding pengetahuan diawal dan akhir edukasi.

\section{Pengetahuan Terhadap Obat DM}

Tingkat pengetahuan diukur dengan instrumen Medication Knowledge Assesment (MKA). Hasil pengukuran tingkat pengetahuan dibagi menjadi 3 (tiga) kriteria yaitu : Tahu Semua (TS), Tahu Sebagian (TB) dan Tidak Tahu (TT).

Apabila responden dapat menjawab seluruh pertanyaan yang terdapat dalamMedication Knowledge Assesment (MKA) untuk seluruh obat yang diterima, maka dimasukkan dalam kategori Tahu Semua (TS). Apabila responden dapat menjawab sebagian (satu atau lebih) dari pertanyaan yang terdapat dalam Medication Knowledge Assesment (MKA) maka dimasukkan dalam kategori Tahu Sebagian (TB). Apabila responden tidak dapat menjawab pertanyaan yang terdapat dalam Medication Knowledge Assesment (MKA) maka dimasukkan dalam kategori Tidak Tahu (TT). Untuk selengkapnya lihat table dibawah ini;

Tabel 1. Persentase Pasien Kelompok 2 Kali Edukasi, Kelompok 3 Kali Edukasi dan Kelompok 4 Kali Edukasi Yang Memiliki Pengetahuan Tentang Obat Pada Awal Penelitian Dan Sesudah Dua Bulan Dengan Instrumen MKA

\begin{tabular}{|c|c|c|c|c|c|c|c|}
\hline \multirow[t]{2}{*}{ Indikator } & \multirow[t]{2}{*}{ Pengetahuan } & \multicolumn{2}{|c|}{$\begin{array}{c}\text { Kelompok } 2 \text { Kali } \\
\text { Edukasi (\%) }\end{array}$} & \multicolumn{2}{|c|}{$\begin{array}{c}\text { Kelompok } 3 \text { Kali } \\
\text { Edukasi (\%) }\end{array}$} & \multicolumn{2}{|c|}{$\begin{array}{c}\text { Kelompok } 4 \text { Kali } \\
\text { Edukasi (\%) }\end{array}$} \\
\hline & & Pre-test & Post-test & Pre-test & Post-test & Pre-test & $\begin{array}{r}\text { Post- } \\
\text { test }\end{array}$ \\
\hline \multirow[t]{3}{*}{ Nama Obat } & Tahu Semua & 40 & 50 & 50 & 60 & 40 & 50 \\
\hline & Tahu Sebagian & 55 & 50 & 35 & 40 & 45 & 50 \\
\hline & Tidak tahu & 5 & 0 & 15 & 0 & 15 & 0 \\
\hline \multirow{3}{*}{$\begin{array}{l}\text { Alasan } \\
\text { Penggunaan }\end{array}$} & Tahu Semua & 10 & 25 & 10 & 15 & 15 & 30 \\
\hline & Tahu Sebagian & 60 & 60 & 50 & 60 & 35 & 45 \\
\hline & Tidak tahu & 30 & 15 & 40 & 25 & 30 & 25 \\
\hline \multirow[t]{3}{*}{ Dosis } & Tahu Semua & 10 & 15 & 5 & 20 & 15 & 25 \\
\hline & Tahu Sebagian & 50 & 55 & 65 & 65 & 40 & 55 \\
\hline & Tidak tahu & 40 & 30 & 30 & 15 & 45 & 20 \\
\hline \multirow[t]{2}{*}{ Waktu Minum } & Tahu Semua & 20 & 40 & 30 & 50 & 45 & 65 \\
\hline & Tahu Sebagian & 80 & 60 & 65 & 50 & 55 & 35 \\
\hline
\end{tabular}




\begin{tabular}{llcccccc}
\hline \multirow{2}{*}{ Efek Positif } & Tidak tahu & 0 & 0 & 5 & 0 & 0 & 0 \\
& Tahu Semua & 10 & 25 & 5 & 20 & 5 & 15 \\
& Tahu Sebagian & 65 & 65 & 65 & 65 & 65 & 70 \\
& Tidak tahu & 25 & 15 & 30 & 15 & 30 & 15 \\
Efek Negatif & Tahu Semua & 0 & 10 & 0 & 5 & 0 & 10 \\
& Tahu Sebagian & 55 & 60 & 55 & 70 & 45 & 55 \\
& Tidak tahu & 45 & 40 & 45 & 25 & 55 & 35 \\
Tempat & Tahu Semua & 35 & 50 & 35 & 55 & 45 & 65 \\
& Tahu Sebagian & 60 & 50 & 65 & 45 & 55 & 35 \\
& Tidak tahu & 5 & 0 & 0 & 0 & 0 & 0
\end{tabular}

Dari Tabel 1, jika dilihat secara keseluruhan dapat diketahui bahwa sebelum diberikan edukasi, semua kelompok penelitian memiliki jumlah responden paling banyak yang "Tahu Semua" mengenai nama obat, waktu minum, dan tempat penyimpanan obat. Jumlah responden yang "Tidak Tahu" mengenai efek negatif dari obat yang digunakan, dosis obat, dan alasan penggunaan obat paling banyak ditemukan pada ketiga kelompok penelitian. Hal ini berarti bahwa selama mengkonsumsi obat diabetes, banyak pasien yang tidak mengetahui mengenai efek samping dari obat yang digunakan, tidak mengingat dosis obat atau berapa banyak obat harus digunakan setiap hari, dan tidak mengetahui mengenai alasan dokter memberikan obat diabetes kepada pasien. Oleh karena itu pada saat memberikan edukasi, farmasis harus melakukan penekanan terhadap topik ini.

Sebelum mendapatkan edukasi, sebagian besar responden "Tahu Sebagian" mengenai obat yang digunakan. Hal ini berarti bahwa mereka belum sepenuhnya mengenal obat-obatan yang mereka gunakan, walaupun sudah lama menderita penyakit DM tipe 2 .

Setelah beberapa kali mendapatkan edukasi (jika dilihat secara keseluruhan), maka terjadi peningkatan pada jumlah responden yang "Tahu Semua" tentang obat dan terjadi pengurangan terhadap jumlah responden yang "Tidak Tahu" mengenai obat DM yang digunakan. Hal ini berarti bahwa edukasi yang diberikan oleh farmasis memberikan respon yang positif bagi pasien.

\section{TINGKAT KEPATUHAN}

\section{Kuadran Kelompok Responden 2 Kali Edukasi, 3 Kali Edukasi dan 4 Kali Edukasi}

Tingkat kepatuhan yang diukur dengan instrumen Modified Morisky Scale (MMS) menggunakan 2 indikator penilaian yaitu motivasi dan pengetahuan yang kemudian dimasukkan ke dalam kuadrankuadran. Sasaran dari edukasi farmasis adalah meningkatkan kepatuhan dengan mengurangi jumlah pasien yang ada pada kuadran I dan II serta menggerakkannya menuju kuadran III dan IV. Seseorang dikatakan patuh bila berada pada kuadran IV (28). 
Tabel 2. Kuadran Kelompok Pasien 2 Kali Edukasi, 3 Kali Edukasi dan 4 Kali Edukasi

\begin{tabular}{|c|c|c|c|c|c|c|c|c|c|c|c|c|c|}
\hline \multirow[t]{3}{*}{ No } & \multirow[t]{3}{*}{ Kuadran } & \multicolumn{4}{|c|}{$\begin{array}{c}\text { Kelompok } 2 \text { Kali } \\
\text { Edukasi }\end{array}$} & \multicolumn{4}{|c|}{$\begin{array}{c}\text { Kelompok } 3 \text { Kali } \\
\text { Edukasi }\end{array}$} & \multicolumn{4}{|c|}{$\begin{array}{c}\text { Kelompok } 4 \text { Kali } \\
\text { Edukasi }\end{array}$} \\
\hline & & \multicolumn{2}{|c|}{ Pre-test } & \multicolumn{2}{|c|}{ Post-test } & \multicolumn{2}{|c|}{ Pre-test } & \multicolumn{2}{|c|}{ Post-test } & \multicolumn{2}{|c|}{ Pre-test } & \multicolumn{2}{|c|}{ Post-test } \\
\hline & & $\Sigma$ & $\%$ & $\Sigma$ & $\%$ & $\Sigma$ & $\%$ & $\Sigma$ & $\%$ & $\Sigma$ & $\%$ & $\Sigma$ & $\%$ \\
\hline 1. & Kuadran I & 7 & 35 & 4 & 20 & 3 & 15 & 1 & 5 & 5 & 25 & 3 & 15 \\
\hline 2. & Kuadaran II & 3 & 15 & 2 & 10 & 3 & 15 & 4 & 20 & 5 & 25 & 4 & 20 \\
\hline 3. & $\begin{array}{l}\text { Kuadaran } \\
\text { III }\end{array}$ & 4 & 20 & 4 & 20 & 7 & 35 & 6 & 30 & 3 & 15 & 3 & 15 \\
\hline 4. & $\begin{array}{l}\text { Kuadaran } \\
\text { IV }\end{array}$ & 6 & 30 & 10 & 50 & 7 & 35 & 9 & 45 & 7 & 35 & 10 & 50 \\
\hline & Total & 20 & 100 & 20 & 100 & 20 & 100 & 20 & 100 & 20 & 100 & 20 & 100 \\
\hline
\end{tabular}

Berdasarkan Tabel 2 dapat diketahui bahwa:

kelompok 2 kali edukasi sebelum edukasi atau pre-test: - responden terbanyak pada Kuadran I yaitu 7 responden (35\%), - responden selanjutnya pada Kuadaran IV yaitu 6 responden (30 $\%)$ - responden pada Kuadaran III sebanyak 4 responden (20\%), -terakhir adalah responden pada Kuadran II sebanyak 3 responden (15\%).

Akan tetapi setelah edukasi (pos-test) diberikan, ternyata jumlah responden terbanyak bergeser menuju Kuadran IV yaitu sebanyak 10 responden (50 \%), jumlah responden yang bergeser menuju Kuadaran I dan Kuadran III adalah sama banyak yaitu 4 responden (20 \%) dan responden yang paling sedikit bergeser menuju Kuadran II yaitu sebanyak 2 responden (10\%)

kelompok 3 kali edukasi sebelum edukasi atau pre-test: responden terbanyak pada Kuadran III dan IV adalah sama banyak yaitu masing-masing 7 responden (35 \%), -responden pada Kuadaran I dan II juga sama banyak yaitu masing-masing 3 responden (15\%). Akan tetapi pada saat post-test (setelah edukasi) diberikan, ternyata jumlah responden terbanyak bergeser menuju Kuadran IV yaitu sebanyak 9 responden (45 \%), kemudian diikuti Kuadran III yaitu 6 responden (30\%), Kuadran II sebanyak 4 responden $(20 \%)$ dan terakhir Kuadran I yaitu sebanyak 1 responden (5\%).

kelompok 4 kali edukasi sebelum edukasi atau pre-test: -responden terbanyak pada Kuadran IV adalah yaitu sebanyak 7 responden (35 \%), -kemudian disusul responden pada Kuadaran I dan II yang sama banyak yaitu masing-masing 5 responden (25 \%) dan - terakhir adalah responden pada Kuadran III sebanyak 3responden (15\%). Setelah edukasi (posttest) jumlah responden terbanyak masih tetap terdapat pada Kuadran IV yaitu sebanyak 10 responden (50\%), kemudian diikuti responden pada Kuadran II sebanyak 4 responden $(20 \%)$ dan terakhir adalah responden pada Kuadran I dan II yang sama banyak jumlahnya yaitu masingmasing 3 responden (15\%).

\section{Total Skor MMS dan Analisis Uji T Berpasangan}

Tingkat kepatuhan yang diukur dengan instrumen Modified Morisky Scale (MMS) menggunakan 2 indikator penilaian yaitu motivasi dan pengetahuan kemudian dilakukan penjumlahan skor motivasi dan 
skor pengetahuan. Hasil analisa statistik dengan uji T berpasangan pada kelompok 2 kali edukasi, 3 kali edukasi dan 4 kali edukasi selengkapnya hat pada tabel V.3. dibawah ini.

Tabel 3 Total Skor dan Uji T Berpasangan Kelompok Responden 2 Kali Edukasi, 3 Kali Edukasi dan 4 Kali Edukasi

\begin{tabular}{|c|c|}
\hline Kelompok Responden & Uji T berpasangan \\
\hline $\begin{array}{lll}\text { Kelompok } & 2 & \text { kali } \\
\text { edukasi } & & \end{array}$ & 0,009 \\
\hline $\begin{array}{l}\text { Kelompok } 3 \text { kali } \\
\text { edukasi }\end{array}$ & 0,004 \\
\hline $\begin{array}{l}\text { Kelompok } 4 \text { kali } \\
\text { edukasi }\end{array}$ & 0,002 \\
\hline
\end{tabular}

Dari tabel diatas diketahui bahwa hasil uji $\mathrm{T}$ berpasangan pre-test dan posttest pada Modified Morisky Scale (MMS) memberikan hasil yang signifikan untuk semua kelompok penelitian. Hal ini berarti bahwa edukasi farmasis dapat meningkatkan kepatuhan pasien pada semua kelompok dan yang paling mendapat nilai tertinggi untuk untuk peningkatan kepatuhan adalah kelompok 4 kali edukasi.

\section{Alasan Ketidakpatuhan}

Penilaian tingkat kepatuhan dengan instrumen Modified Morisky Scale (MMS) kepada responden kemudian dilanjutkan dengan melakukan wawancara mendalam Deep interview) untuk mengetahui alasan atau penyebab dari ketidakpatuhan responden 
Tabel 4. Alasan Ketidakpatuhan Pengobatan Responden Kelompok 2 Kali Edukasi, Kelompok 2 Kali Edukasi Dan Kelompok 2 Kali Edukasi

\begin{tabular}{|c|c|c|c|c|c|c|}
\hline \multirow[t]{2}{*}{ Alasan Ketidakpatuhan } & \multicolumn{2}{|c|}{$\begin{array}{c}\text { Kelompok } 2 \text { Kali } \\
\text { Edukasi }\end{array}$} & \multicolumn{2}{|c|}{$\begin{array}{l}\text { Kelompok } 3 \text { Kali } \\
\text { Edukasi }\end{array}$} & \multicolumn{2}{|c|}{$\begin{array}{l}\text { Kelompok } 4 \text { Kal } \\
\text { Edukasi }\end{array}$} \\
\hline & $\Sigma$ & $\%$ & $\Sigma$ & $\%$ & $\Sigma$ & $\%$ \\
\hline 1. Lupa & 9 & 45 & 6 & 30 & 6 & 30 \\
\hline 2. Sengaja & 4 & 20 & 6 & 30 & 5 & 25 \\
\hline $\begin{array}{l}\text { 3. Tidak Tahu Aturan Pakai } \\
\text { Obat }\end{array}$ & 2 & 10 & 5 & 25 & 4 & 20 \\
\hline $\begin{array}{l}\text { 4. Minum Obat Tergantung } \\
\text { Orang Lain }\end{array}$ & 2 & 10 & 1 & 5 & 3 & 15 \\
\hline $\begin{array}{l}\text { 5. Jumlah Obat Yang } \\
\text { Diperoleh Kurang }\end{array}$ & 2 & 10 & 1 & 5 & 1 & 5 \\
\hline 6. Tidak Mendapatkan Obat & 1 & 5 & 0 & 0 & 0 & 0 \\
\hline 7. Harga Obat Mahal & 0 & 0 & 1 & 5 & 1 & 5 \\
\hline JUMLAH & 20 & 100 & 20 & 100 & 20 & 100 \\
\hline
\end{tabular}

Dari Tabel 4 diatas dapat diketahui bahwa:

- Pada kelompok 2 kali edukasi alasan ketidakpatuhan pengobatan yang terbanyak adalah faktor lupa yaitu sebanyak 9 responden (45 \%) dan alasan tidak mendapatkan obat hanya dijawab oleh 1 responden (5 \%) serta tidak ada yang mengaku karena alasan harga obat yang mahal.

-Pada kelompok 3 kali edukasi alasan ketidakpatuhan pengobatan yang terbanyak adalah faktor lupa dan faktor sengaja yang sama banyak yaitu masing-masing 9 responden (30\%), kemudian alasan minum obat tergantung orang lain dan alasan jumlah obat yang diperoleh kurang masingmasing 1 responden (5\%) dan tidak ada yang mengaku karena karena tidak mendapatkan obat.
-Pada kelompok 4 kali edukasi alasan ketidakpatuhan pengobatan yang terbanyak adalah faktor lupa yaitu sebanyak 6 responden (30\%) kemudian disusul alasan faktor sengaja sebanyak 5 responden ( 25 $\%$ ), alasan faktor tidak tahu aturan pakai obat sebanyak 4 responden (20\%) dan tidak ada yang mengaku alasan karena tidak mendapatkan obat.

\section{GULA DARAH}

Pemeriksaan gula darah merupakan satu-satunya variabel yang bersifat objektif dan terukur dengan standar yang sudah ditetapkan. Seluruh responden pada kelompok 2 kali edukasi, kelompok 3 kali edukasi dan kelompok 4 kali edukasi dilakukan pemeriksaan kadar gula darah 
saat pre-test (pertemuan pertama) dan saat post-test (pertemuan terakhir).

Hasil pemeriksaan gula darah ini kemudian diambil nilai rata-rata (mean) untuk tiap kelompok.

Kemudian dilakukan uji statistik untuk membandingkan rata-rata kadar gula darah pre-test dan post-test pada kelompok yang sama. Selain itu juga dilakukan uji statistik kadar gula darah pre-test dan post-test antar kelompok yaitu kelompok 2 kali edukasi dibandingkan dengan kelompok 3 kali edukasi, kelompok 2 kali edukasi dibandingkan dengan kelompok 4 kali edukasi dan kelompok 3 kali edukasi dibandingkan dengan kelompok 4 kali edukasi.

\section{Gula Darah Puasa (GDP)}

Tabel 5. Rerata Hasil Uji T Independen dan Uji T Berpasangan Gula Darah Puasa (GDP) Pasien Kelompok 2 Kali Edukasi, Kelompok 3 Kali Edukasi dan Kelompok 4 Kali Edukasi Sebelum Dan Sesudah Edukasi

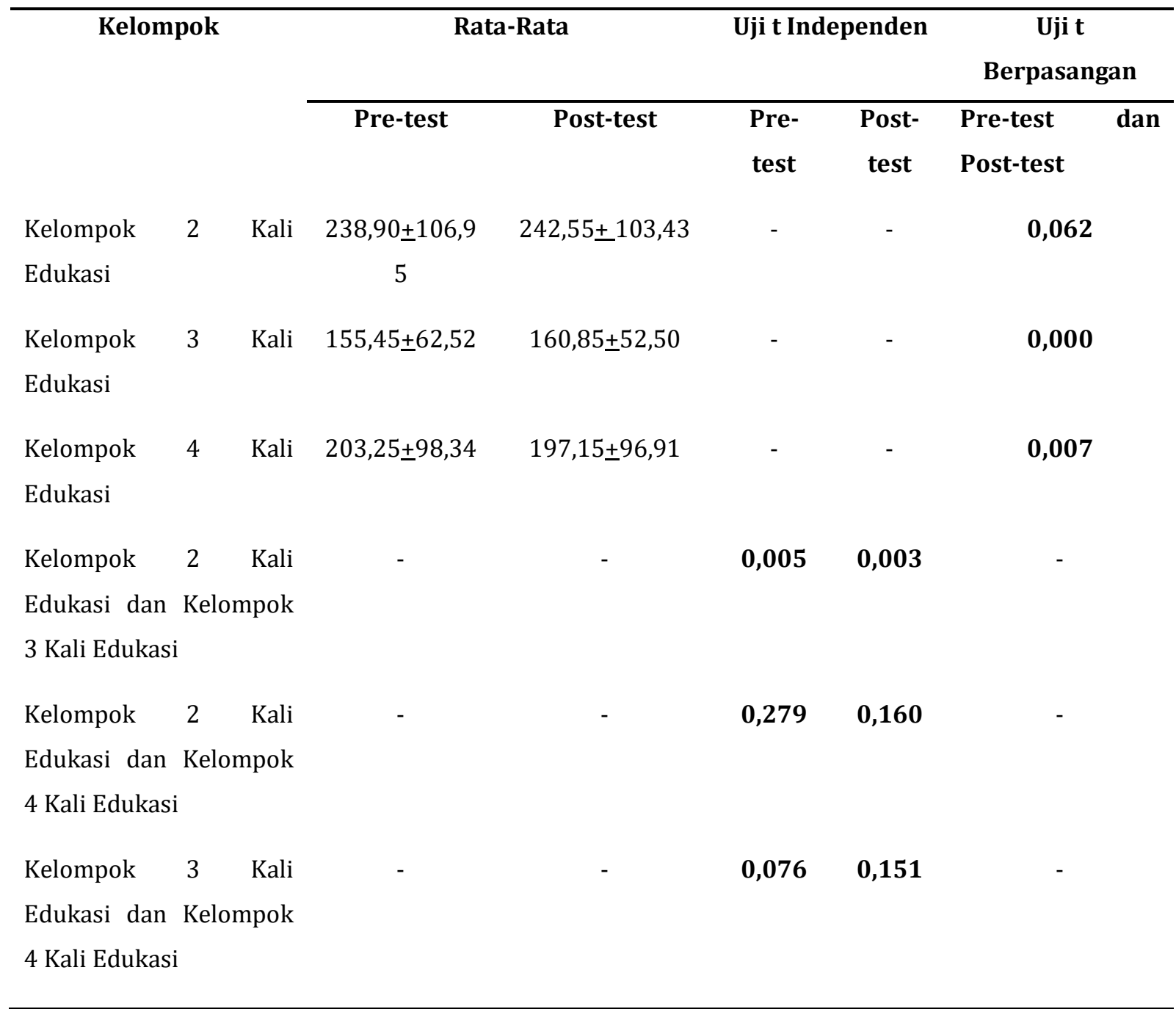

Hasil uji $t$ berpasangan menunjukkan bahwa tidak terdapat perbedaan rerata yang signifikan pada kelompok 2 kali edukasi $(0,062)$ Hal ini berarti bahwa edukasi yang diberikan oleh farmasis sebanyak 2 kali tidak memberikan pengaruh terhadap kadar gula darah puasa pasien. Hasil uji $t$ berpasangan pada kelompok 3 kali edukasi dengan 4 kali edukasi memberikan hasil yang siginifikan. Hal ini berarti bahwa terdapat perbedaan antara rerata kadar gula darah puasa pasien 
sebelum dan sesudah mendapatkan edukasi farmasis. Sehingga dapat disimpulkan bahwa edukasi farmasis mempengaruhi kadar gula darah puasa pasien.

Hasil uji $t$ independen antara kelompok 2 kali edukasi dan kelompok 3 kali edukasi menunjukkan bahwa sebelum edukasi diberikan sudah terdapat perbedaan yang signifikan pada kadar gula darah puasa antara kedua kelompok tersebut. Setelah mendapatkan edukasi, kedua kelompok ini juga memberikan hasil yang signifikan. Akan tetapi hasil ini tidak dapat disimpulkan bahwa penyebabnya adalah karena edukasi farmasi.

\section{Gula Darah 2 Jam Setalah Makan (GD2JPP}

Tabel 6 Rerata Hasil Uji T Independen dan Uji T Berpasangan GD 2JPP Pasien Kelompok 2 Kali Edukasi, Kelompok 3 Kali Edukasi dan Kelompok 4 Kali Edukasi Sebelum Dan Sesudah Edukasi

\begin{tabular}{|c|c|c|c|c|c|}
\hline \multirow[t]{2}{*}{ Kelompok } & \multicolumn{2}{|c|}{ Rata-Rata (\%) } & \multicolumn{2}{|c|}{ Uji t Independen } & \multirow{2}{*}{$\begin{array}{c}\text { Uji t } \\
\text { Berpasangan } \\
\text { Pre-test dan }\end{array}$} \\
\hline & Pre-test & Post-test & Pre-test & Post-test & \\
\hline & & & & & Post-test \\
\hline \multirow[t]{2}{*}{ Kelompok 2 Kali Edukasi } & $321,10 \pm$ & $319,95 \pm$ & - & - & 0,070 \\
\hline & 164,64 & 161,89 & & & \\
\hline \multirow[t]{2}{*}{ Kelompok 3 Kali Edukasi } & $185,60 \pm$ & $182,45 \pm$ & - & - & 0,000 \\
\hline & 65,43 & 61,26 & & & \\
\hline \multirow[t]{2}{*}{ Kelompok 4 Kali Edukasi } & $250,00 \pm$ & $237,75 \pm$ & - & - & 0,000 \\
\hline & 98,91 & 90,20 & & & \\
\hline Kelompok 2 Kali Edukasi dan & - & - & 0,002 & 0,001 & - \\
\hline \multicolumn{6}{|l|}{ Kelompok 3 Kali Edukasi } \\
\hline Kelompok 2 Kali Edukasi dan & - & - & 0,108 & 0,057 & - \\
\hline \multicolumn{6}{|l|}{ Kelompok 4 Kali Edukasi } \\
\hline Kelompok 3 Kali Edukasi dan & - & - & 0,020 & 0,019 & - \\
\hline Kelompok 4 Kali Edukasi & & & & & \\
\hline
\end{tabular}

Dari Tabel 6, diatas dapat diketahu bahwa hasil uji t berpasangan menunjukkan bahwa tidak terdapat perbedaan rerata yang signifikan pada kelompok 2 kali edukasi antara kadar gula darah 2 jam PP pasien sebelum dan sesudah edukasi farmasis. Hal ini berarti bahwa edukasi yang diberikan oleh farmasis sebanyak 2 kali belum dapat mempengaruhi kadar gula darah 2 jam PP pasien pada kelompok 2 kali edukasi. Hasil uji t berpasangan pada kelompok 3 kali edukasi dengan 4 kali edukasi memberikan hasil perbedaan rerata yang siginifikan terhadap kadar gula darah 2 jam PP pasien sebelum dan sesudah edukasi farmasis. Hal ini berarti bahwa edukasi yang diberikan sebanyak 3 kali dan 4 kali sudah dapat mempengaruhi kadar gula darah 2 jam PP pasien.

Hasil uji $t$ independen antara kelompok 2 kali edukasi dan kelompok 3 kali edukasi dengan 4 kali edukasi menunjukkan bahwa pada keadaan awal diantara dua kelompok tersebut sudah 
terdapat perbedaan rerata gula darah 2 jam PP yang signifikan. Nilai uji t independen sesudah edukasi juga memberikan hasil yang signifikan, namun tidak dapat dipastikan bahwa perbedaan rerata yang signifikan ini disebabkan oleh edukasi farmasis.

Hasil uji t independen antara kelompok 2 kali edukasi dengan 4 kali edukasi menunjukkan hasil yang tidak signifikan baik sebelum mendapatkan edukasi maupun setelah mendapatkan edukasi. Hal ini berarti bahwa edukasi farmasis tidak mempengaruhi kadar gula darah 2 jam PP pasien yang berada pada kelompok tersebut dan frekuensi edukasi tidak mempengaruhi kadar gula darah 2 jam PP pasien.

\section{Uji Korelasi (Bivariate)}

Tabel 7 Hasil Uji Korelasi (Bivariat)

\begin{tabular}{lc}
\hline \multicolumn{1}{c}{ Variabel yang Dibandingkan } & $\begin{array}{c}\text { Nilai Signifikansi } \\
\text { (Korelasi Pearson) }\end{array}$ \\
\hline Kepatuhan Vs Kadar Gula Darah Puasa Setelah Edukasi & $0,526(-0,082)$ \\
Kepatuhan Vs Kadar Gula Darah 2 Jam PP Setelah Edukasi & $0,833(-0.028)$ \\
Kepatuhan Setelah Edukasi Vs Frekuensi Edukasi & $0,731(0,45)$ \\
Kadar Gula Darah Puasa Setelah Edukasi Vs Frekuensi Edukasi & $0,120(-0,203)$ \\
Kadar 2 Jam PP Sesudah Edukasi Vs Frekuensi Edukasi & $0,036(-0,272)$ \\
\hline
\end{tabular}

Dari Tabel 7, diatas dapat diketahui bahwa kepatuhan pasien DM tipe 2 di RS Bayu Asih tidak memiliki korelasi dengan kadar gula darah puasa maupun kadar gula darah 2 jam PP. Kepatuhan setelah edukasi juga tidak memiliki korelasi dengan frekuensi edukasi. Frekuensi edukasi tidak berkorelasi dengan kadar gula darah puasa namun berkorelasi negatif dengan kadar gula darah 2 jam PP. Hal ini berarti bahwa nilai kadar gula darah 2 jam PP akan berubah setelah mendapatkan edukasi. Pasien yang semakin sering mendapatkan edukasi.

\section{KESIMPULAN}

1. Edukasi farmasis dapat meningkatkan pengetahuan pasien DM tipe 2 pengguna insulin terhadap pengobatannya di Poliklinik Penyakit Dalam RSUD Bayu Asih Kabupaten Purwakarta. Prosentase responden pada semua kelompok perlakuan (kelompok 2 kali edukasi, 3 kali edukasi, dan 4 kali edukasi) yang "tahu semua" mengenai obat yang dikonsumsinya, meningkat secara signifikan pada saat dilakukan post-test.

2. Edukasi farmasis dapat meningkatkan kontrol glikemik pasien DM tipe 2 yang menjalani pengobatan rutin dengan insulin di Poliklinik Penyakit Dalam RSUD Bayu Asih Kabupaten Purwakarta. Prosentase responden dari semua kelompok perlakuan yang berada pada Kuadran IV MMS meningkat secara signifikan dari pretest ke post-test.

\section{DAFTAR PUSTAKA}

1. Basuki E. dkk. Buku Acuan Penatalaksanaan Diabetes Mellitus Bagi Dokter Puskesmas, Dokter Praktek Umum dan Edukator Diabetes. Pusat Diabetes dan Lipid RSUPN DR. Cipto Mangun Kusumo Fakultas Kedokteran Universitas Indonesia, Jakarta, 2003.

2. Soegondo. Diagnosis dan Klasifikasi Diabetes Mellitus Terkini Dalam Sidartawan Soegondo, Pradana Soewondo dan Imam Subekti (ed): 
Penatalaksanaan Diebetes Mellitus Terpadu. Cetakan IV. Jakarta: Balai Penerbit FKUI, 2002. Hal 17-27.

3. Departemen Kesehatan Republik Indonesia. Phamaceutical Care untuk Penyakit Diabetes Melitus, Jakarta: Direktorat Bina Farmasi Komunitas dan Klinik. 2005.

4. Anonim. Profil Rumah Sakit Umum Daerah (RSUD) Bayu Asih Kabupaten Purwakarta Tahun 2011, Purwakarta. 2011.

5. Aslam M, Tan CK, Prayitno A. Farmasi Klinis: Menuju Pengobatan Rasional dan Penghargaan Pilihan Pasien. Jakarta: PT Elex Media Komputindo Gramedia. 2007.

6. Jepson, M.H. Patient Compliance and Counselling, Diana M., Aulton, ME. (Editor), London: Pharmaceutical Practice, Churscill Livingstone. 1990.

7. Asti, Tri. Kepatuhan Pasien: Faktor Penting dalam Keberhasilan Terapi. Info POM, Vol. 7, No. 5 dari http://perpustakaan.pom.go.id. 2006.

8. Anonim. Pelayanan Konseling Akan Meningkatkan Kepatuhan Pasien Pada Terapi Obat, diakses Januari 2013 dari http://indonesiasehat. blogspot.com. 2007.

9. Schnipper JL, dkk. Role of Pharmacist Counseling in Preventing Adverse Drug Events After Hospitalization. USA: Archives of Internal Medicine. 2006. Vol 166.565-571.

10. American Nurses' Association, Council of Community Health Nurses. "Standards of Community Health Nursing Practice". Kansas city: ANA. 1988.

11. Brunner dan Suddarth. Keperawatan medical bedah. Jakarta. Penerbit Buku Kedokteran EGC. Jakartra. 2001.

12. Andayani TM. Analisis biaya terapi Diabetes mellitus di Rumah Sakit Dr. Sardjito Yogyakarta. Majalah Farmasi Indonesia Vol 17(3). Hal 130-135. 2006.

13. Renova. Karakteristik Penderita DM
Yang Dirawat Inap Di RS. Santa Elisabeth Medan Tahun 2007. Skripsi FKM Universitas Sumatera Utara (USU). Medan. 2008.

14. Hendro Martono. Peran Radikal Bebas Terhadap Komplikasi Vaskuler DM

Tipe 2. volume 1. NO 2. Mei 2000. hlm 88-93. FK UDAYANA. Bali. 2000. Suryoko K. Gambaran Epidemiologi Penderita Diabetes Mellitus Pasien Rawat Inap di Rumah Sakit Umum Daerah Budhi Asih Jakarta Tahun 1997 - 2000. Skripsi FKM UI. Jakarta. 2002.

15. Tjokroprawiro A. Diabetes Mellitus: Klasifikasi, Diagnosis dan Terapi. Edisi Ketiga. Penerbit PT. Gramedia Pustaka Utama. Jakarta. 2002.

16. Arcole Margatan. Hidup Sehat Bagi Usia Lanjut, Jakarta: Penerbit Buku Kedokteran EGC. Jakarta. 1996.

17. Safarino, E.P. Health Psychology: Biopsychosocial Interactions. Third Edition. New York: John Wiley \& Sons, Inc. 1998.

18. Notoatmodjo, Soekidjo. Pendidikan Dan Perilaku Kesehatan. Penerbit Rineka Cipta. Jakarta. 2003.

19. Rantucci MJ. Komunikasi ApotekerPasien: Panduan Konseling Pasien (Edisi 2). Penerjemah: A.N. Sani. Penerbit Buku Kedokteran EGC. Jakarta. 2007.

20. Siregar, Charles JP dan Endang Kumolosasi. Farmasi Klinik Teori dan Penerapan, Jakarta: Penerbit Buku Kedokteran EGC. 2002.

21. Soegondo, Sidartawan dan Pradana Soewondo. 2002. Penatalaksanaan Diebetes Mellitus Terpadu. Jakarta: Balai Penerbit FKUI. Jakarta. 2006.

22. Basuki, Endang. Konseling Medik: Kunci Menuju Kepatuhan Pasien. Majalah Kedokteran Indonesia. Jakarta. 2009. Vol 59 Nomor 2 Februari 2009.

23. Eni P, Zullies I, Dewa PP: Hubungan Kepatuhan Penggunaan Obat Dengan Persistensi Pengisian Obat Askes Pada Pasien Hipertensi Di RSUP Dr. Sardjito Yogyakarta dalam Prosiding Seminar Nasional Eight 
Star Performance Pharmacist, Magister Farmasi Klinik UGM, Yogyakarta. 2010.

24. Pelayanan Informasi Obat di Rumah Sakit; diambil dari website: (http://farmasiqt.wordpress.com/2 011/04/05/pelayanan-informasiobat-di-rumah-sakit/)

25. Keban SA. Pengaruh edukasi farmasis terhadap kontrol glikemik pasien diabetes melitus tipe 2 pengguna insulin di Poliklinik Penyakit Dalam RSUP DR. SARDJITO Yogyakarta periode Desember 2007-Juni 2008. Yogyakarta. S2 Farmasi Klinik Pascasarjana UGM Yogyakarta. 2008.

26. Palestin B, dkk. Penerapan Komunikasi Teurapetik untuk mengoreksi Perilaku Klien Rawat Jalan dengan Diabetes Mellitus. http ://annagustinazblogspot.com. 2002.
27. Anonim. Case Management Adherence Guidelines (CMAG) Version 2.0: Guidelines from the Case Management Society of America for improving patient adherence to medication therapies 2006 Case Management Society of America. 2006.

28. Sugiyono, Dr. Metode penelitian Kuantitatif Kualitatif dan R\&D, Penerbit ALFABETA. Jakarta. 2010.

29. Notoadmojo S. Metodologi Penelitian Kesehatan. Jakarta: PT. Rineka Cipta. Jakarta. 2005 Halaman 79-92, 112-115, 117-136

30. Nadyah A, Yuanita AL, Karel Pandelaki. Gambaran Faktor Resiko Pasien Diabetes Melitus Tipeii Di Poliklinik Endokrin Bagian/SMF FKUNSRAT RSU Prof.Dr. R.D Kandou Manado Periode Mei 2011 - Oktober 2011. Skripsi FK UNSRAT Manado 